\title{
KEDUDUKAN KAIDAH KEBAHASAAN DALAM KAJIAN TAFSIR
}

\author{
Ali Mutakin \\ Sekolah Tinggi Agama Islam Nurul Iman \\ Jl. Nurul Iman No. 1 Ds. Warujaya Rt. 01/01 Kec. Parung Kab. Bogor 16330 \\ Email: nabilamandor@gmail.com
}

\begin{abstract}
This article explores the higher beautiful of Arabic and shows message texts which interpreted. Necessary, It is understanding the Arabic language as language from Qur'anic. Significantly, it's Arabic has standardization of Mufassir salaf in principle Arabic language. In studies of tafsir, the principal Arabic language has a self-position which significant. This research employs descriptive-analysis to showed a position of the principal Arabic language which used. This article aims to answer that principle the Arabic language has been made by Mufassir of salaf as support understanding of Qur'anic is relevant.
\end{abstract}

\section{Keywords:}

Arabic; arabic grammar; Tafsir.

\begin{abstract}
Abstrak
Tulisan ini berusaha untuk menunjukkan bahwa Alquran mempunyai keindahan bahasa Arab yang tinggi, serta menunjukan teks sebagai pesan yang perlu ditafsirkan. Sebab itu, perlu dipahami dengan bahasa Arab sebagai bahasa turunnya Alquran, yang menunjukan pesan-pesan ilahiah kepada manusia. Peranan penting bahasa Arab telah dijewantahkan dalam kaidah kebahasaan. Maka dalam kajian tafsir terdapat kaidah kebahasaan yang mempunyai kedudukan tersendiri yang sangat vital. Penelitian ini menggunakan metode deskriptif-analisis untuk menunjukan kedudukan kaidah-kaidah kebahasaan yang digunakan. Sehingga penilitan ini diharapkan mampu menjawab bahwa kaidah bahasa Arab yang telah dicetuskan oleh Ulama terdahulu masih relevan dan masih diperlukan sebagai penunjang memahami Alquran dalam meminimalisir terjadinya kekeliruan.
\end{abstract}

Kata Kunci:

Bahasa Arab; Kaidah Kebahasaan; Tafsir.

\section{A. PENDAHULUAN}

The religious commitment is covered in three major Islamic teachings: Iman (faith), Islam (surrender to Allah), and Ihsan (state of being observed by Allah) ${ }^{1}$. Hal ini adalah landasan kita harus mempelajari Alquran.

Alquran merupakan salah satu kitab samawi yang mempunyai fungsi petunjuk (hudan) dan pedoman hidup manusia (way of life), serta akan selalu compatible dengan segala perubahan zaman akibat pengaruh globalisasi kehidupan. Bahasa Alquran memiliki keagungan dan begitu mempesona, redaksinya berisi mutiara-mutiara yang memiliki nilai-nilai sepanjang masa. Oleh

\footnotetext{
${ }^{1}$ Fenti Hikmawati, "Islamic Counselling Model to Increase Religious Commitment (Study of Students at the University UIN Bandung)," International Journal of Nusantara Islam 1, no. 1 (2013): 65.
}

karena itu, tugas umat Islam adalah memberikan perhatian yang serius dalam mempelajari, menghayati sekaligus mengamalkannya agar kemanfaatannya dapat dirasakan dalam kehidupan bersama. Imam Al-Zamakhsari menyebutkan bahwa Sungguh telah datang kepadaku sahabat-sahabatku dari golongan orang-orang yang mulia, selamat dan adil, mereka menguasai ilmu bahasa Arab dan tauhid. ${ }^{2}$ Bangsa Arab terkenal dengan sebutan ashab al-fashahah (fasih berbahasa) dan ahl al-balaghah (memiliki cita rasa bahasa tinggi), dalam kenyataanya mereka

2 Muhammad Solahudin, "Metodologi Dan Karakteristik Penafsiran Dalam Tafsir Al-Kashshaf," Wawasan: Jurnal Ilmiah Agama Dan Sosial Budaya 1, no. 1 (2016): 119. 
tidak mampu untuk membuat karya guna menandingi keindahan bahasa Alquran. ${ }^{3}$

Bangsa Arab terkenal dengan sebutan ashab al-fashahah (fasih berbahasa) dan ahl albalaghah (memiliki cita rasa bahasa tinggi), dalam kenyataanya mereka tidak mampu untuk membuat karya guna menandingi keindahan bahasa Alquran. ${ }^{4}$

Dalam surat Yusuf ayat 2 Allah berfirman:

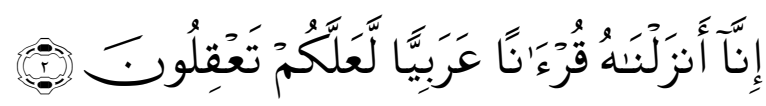

Artinya: "Sesungguhnya kami menurunkannya berupa Alquran dengan berbahasa Arab, agar kamu memahaminya".

Secara tegas, dalam ayat tersebut dijelaskan bahwa Allah menyampaikan firman-Nya dalam bahasa Arab. Dengan demikian, agar pesan-pesan Alquran bisa tersampaikan kepada seluruh lapisan umat manusia khususnya umat Islam, maka perlu diketahui makna-makna firman Allah Swt. maka penafsiran Alquran merupakan sebuah keniscayaan yang tidak bisa dihindari dan sangat dibutuhkan. Pada saat itulah, peran kaidah-kaidah kebahasaan menjadi sangat penting untuk dipelajari guna mencapai pemahaman yang baik dan benar. Quraish Shihab mengatakan salah satu keistimewaan bahasa Arab adalah adanya i'rab. ${ }^{5}$ Dengan demikian Alquran harus dipahami dan ditafsirkan dengan menggunakan pendekatan kaidah-kaidah bahasa Arab, sehingga dapat diketahui ketinggian nilai-nilai dan kedudukan Alquran, sebab dengan menguasai kaidah kebahasaan mampu memudahkan seseorang dalam menafsirkan Alquran. Bahkan menurut Imam al-Zarwani sebagaimana dikutip Imam

\footnotetext{
${ }^{3}$ Lihat QS. Al-Baqarah [2]: 23, QS. Hud [11]: 13, QS. Al-Isra' [17]: 88

${ }^{4}$ Lihat QS. Al-Baqarah [2]: 23, QS. Hud [11]: 13, QS. Al-Isra' [17]: 88

${ }^{5}$ Quraish Shihab, Mu'jizat Alqurandi Tinjau Dari Aspek zkebahasaan Isyarat Ilmiah dan Pemberitaan Ghaib (Bandung: Mizan, 2003), 98
}

al-Zarqani menjelaskan bahwa orang yang tidak memenuhi syarat-syarat sebagai seorang mufasir (memahami kaidah kebahasaan) produk tafsirnya dikategorikan sebagai produk tafsir terendah, bahkan belum bisa disebut sebagai tafsir. ${ }^{6}$ Dengan demikian tidak mengherankan, apabila Bahasa Arab dan Alquran menempati posisi paling sentral dalam studi-studi keislaman.

\section{B. HASIL DAN PEMBAHASAN \\ 1. Pandangan Ulama tentang Tafsir}

Tafsir adalah inti ajaran Islam yang paling dijaga ortodoksinya. Kata tafsir merupakan serapan dari bahasa Arab al-tafsir (التفسير), yang masih diperdebatkan tentang asal muasal (ishtiqaq) nya. Hal ini bisa dilihat dari pendapat-pendapat mereka tentang makna tafsir secara bahasa. Pertama, kata al-tafsir berasal dari al-tafsirah yang berarti sebuah riset yang dilakukan oleh seorang dokter pada urine pasien untuk mengetahui penyakit yang dideritanya. Hal ini dianalogikan dengan seorang yang hendak menafsirkan Alquran dengan cara meneliti serta mengamatinya untuk bisa mengeluarkan dan mengambil makna dan hukum yang terkandung dibalik teks Al-Quran. Pendapat ini dikemukakan oleh al-Zarkasyi. ${ }^{7}$ Arti demikian, juga ditunjukan oleh kata al-fasr (الفسر)sebagaimana yang terdapat dalam beberapa kamus bahasa Arab. ${ }^{8}$

Kedua, kata al-tafsir diambil dari ungkapan fassartu al-fars (فسرت الفرس) yang berarti melepaskan kuda.Hal ini dianalogikan bahwa seorang mufasir yang melepaskan seluruh kemampuan berfikirnya untuk bisa mengurai makna ayat Alquran yang tersembunyi dibalik teks dan sulit untuk dipahami. ${ }^{9}$ Ketiga, kata al-tafsir merupakan

6 Lihat Muhammad Abd. Al-Dim Al-Zarqān̄̄, Manāhil al-Irfaān F̄̄ 'ulūm al-Qur'ān (Beirut: Dār alFikr, tt.), 519

Badr al-Din al-Zarkashi, al-Burhan fi Ulūm Alquran (Beirut: Dar al-Kutub al-Ilmiyah, 2006), 331

${ }^{8}$ Ibn Faris, Mu'jam Maqayis al-Lughah, vol. IV (Beirut: Dar al-Fikr, 1979), 504

9 Syihab al-Din al-Alusi, Ruh al-Ma'ani, vol. I (Beirut: Ihya' al-Turath al-Arabi, t.t, 4 
kata turunan dari kata al-fasr (الفسر) yang mengikuti pola kata al-taf'il (التفعيل). Pendapat ini diikuti banyak ulama seprti Abu Hayyan dan al-Suyuti. ${ }^{10}$

Dari uraian-uraian yang dijelaskan diatas, definisi tafsir secara bahasa tidak jauh dari makna terbuka dan jelas.Yaitu membuka dan menjelaskan sesuatu yang belum jelas.

Sedangkan menurut istilah ulama juga belum menemukan kata sepakat dalam mendefinisikannya. Menurut al-Zarkasyi yang dikutip oleh al-Suyuthi tafsir merupakan sebuah disiplin ilmu yang digunakan untuk memahami kitabullah yang diturunkan kepada Nabi Saw.dan menjelaskan makna-makna yang terkandung di dalamnya serta mengeluarkan hokum-hukum dan berbagai hikmah darinya. ${ }^{11}$ Sementara Manna' alQaththan menyatakan bahwa tafsir adalah penjelasan-penjelasan kalam Allah Swt. yang bernilai ibadah ketika dibaca yang diturunkan kepada nabi Saw. Seperti yang diungkapkan Fatmawati dalam tulisannya, "historical events played by prophet Mohammed is something ideal to be followed by Muslims". ${ }^{12}$ terlepas dari pandangan-pangan tersebut, tafsir merupakan sebuah istilah yang digunakan dalam rangka upaya memahami Alquran. Dengan demikian, sesungguhnya dalam tafsir tidak lepas dari tiga konsep yang terkandung di dalamnya. Pertama, kegiatan ilmiah yang berfungsi untuk memahami dan menjelaskan kandungan Al-Qur'an. Kedua, ilmu-ilmu yang digunakan dalam kegiatan tersebut, dan ketiga ilmu yang menjadi produk kegiatan ilmiah tersebut. Karena Islam sebagai objek studi merupakan topik yang atraktif diperbincangkan di kalangan ilmuwan. Ketiga konsep tersebut tidak bisa lepas dari tafsir, hal ini disebabkan karena ia berperan sebagai alat, proses dan hasil capaian sebuah penafsiran.

10 Abu Hayyan, Tafsir al-Bahr al-Muhit, vol. I (Beirut: Dar al-Kutub al-Ilmiyyah, 1993,), 9. Jalal alDin al-Suyuti, al-Itqan, Vol. II (Beirut: Dar al-Fikr, t.t.), 173

11 Jalal al-Din al-Suyuti, al-Itqan ... 174

12 Prophet Muhammad, "Inter-Religious Relations In The Period Of," Al-Albab 5, no. 2 (2016): 175.
Terkadang istilah al-tafsir disamakan dengan al-ta'wilyang berasal dari kata al-awla yang mengikuti pola kata taf'il yang berarti kembali kepada keadaan semula. Ini merupakan salah satu dari beberapa makna dari kata al-awla. ${ }^{13}$ Hal ini dimaksudkan bahwa seorang penafsir Alquran menguraikanya sedemikian rupa berdasarkan pokok pengertian yang terkandung di dalam ayat itu sendiri. ${ }^{14}$

Tafsir Alquran mempunyai sejarah panjang dengan serangkaian tokoh yang ada didalamnya. Sejarah tafsir dimulai dari penafsiran yang dilakukan oleh Nabi saw. ketika para sahabat menemui ayat-ayat Alquran yang belum jelas maknanya, maka sahabat langsung bisa menanyakan kepada Nabi Saw untuk menjelaskan ayat-ayat tersebut. ${ }^{15}$ Meskipun demikian, tidak semua ayat yang terkandung dalam Alquran dijelaskan oleh Nabi. Beliau hanya menjelaskan ayat-ayat yang makna serta maksudnya tidak diketahui oleh para sahabat. Ayat-ayat tersebut meliputi ayat-ayat yang bersifat global dan sukar dipahami, yang masih butuh perincian atau kejelasan dan juga ayat-ayat yang hanya bisa dimengerti oleh orang yang cerdas dan pandai.Begitu pula ayat-ayat yang menerangkan tentang hal-hal gaib, yang tidak ada seorangpun mengetahui kecuali Allah Swt., seperti terjadinya hari kiamat, dan hakikat ruh.Sedangkan ayat yang bisa dipahami melalui aspek kebahasaan serta ayat-ayat yang berisikan hal-hal yang mudah dinalar tidak dijelaskan dan ditafsirkan oleh Nabi Saw. ${ }^{16}$ Tujuan disyariatkannya Islam

\footnotetext{
${ }^{13}$ Diantaranya adalah al-ta'wil berasal dari akar kata al-iyalah, yang mempunyai arti pengaturan atau siasat. Makna-makna yang lain bisa dilihat dari berbagai ayat seperti QS. Ali Imran [03]: 7. QS. Al-Nisa [04]: 59. QS. Al-Kahfi [18]: 82. Lihat Muhammad Husain alDzahabi, al-tafsir wa al-Mufassirun, Vol. I (Kairo: Maktabah wahbah, 2003), 15. Nur Kholis, Pengantar studi Alqurandan Hadist (Yogyakarta: Teras, 2008), 135

${ }^{14}$ Lihat Nur Kholis, Pengantar studi Alqurandan Hadist... 135

${ }^{16}$ Lihat Muhammad Husain al-Dzahabi, al-tafsir wa al-Mufassirun...39
} 
adalah untuk kemaslahatan hidup manusia baik rohani maupun jasmani, individual maupun kelompok. ${ }^{17}$

Penjelasan dan penafsiran oleh Nabi ini dikarenakan beliau yang menerima wahyu dan menyampaikannya kepada umat manusia, tentu lebih memahami kandungan Al-Qur'an, baik secara global maupun rinci.Mengenai jumlah ayat yang ditafsirkan oleh Nabi, para ulama berbeda pendapat.Menurut pendapat yang didukung Ibnu Taimiyah bahwa Nabi telah menjelaskan seluruh ayat Alqurankepada para sahabatnya.Sedangkan menurut pendapat yang didukung oleh khuwaibi dan al-Suyuthi bahwa Nabi hanya menjelaskan sebagian makna-makna ayat Alqurankepada para sahabat. $^{18}$

Setelah pasca kemangkatan Nabi, penafsiran Alqurandilakukan oleh sahabat yang merupakan kelompok yang paling dekat dengan peristiwa pewahyuan. Meskipun demikian tidak semua para sahabat mempunyai tingkat daya tangkap (intelegen) dan pemahaman makna Alquranyang sama. Hal ini disebabkan oleh kemampuan akal dan pengetahuan mereka dalam memahami Alquranberbeda. ${ }^{19}$

Dalam menafsirkan Al-Qur'an, sumber yang dipakai oleh sahabat ada empat, yaitu Al-Qur'an, hadits, ijtihad dan serta keterangan ahli kitab yaitu Yahudi dan Nasrani. Mulamula sahabat dalam menafsirkan suatu ayat Alquran lebih dulu mencarinya dalam AlQur'an, apakah terdapat penjelasan atau tidak .Jika tidak menemukan ayat yang menafsirkannya, mereka beralih ke hadits Nabi Saw. Apabila tidak menemukan ayat Alquran dan hadits yang bisa menafsirkannya, maka mereka melakukan ijtihad dengan segala kemampuan yang dimilikinya. Pada tahap berikutnya, sahabat menyandarkan

17 Qosim, "Analysis of Critical Thought Wahbah Wahbah Az-Zuhailī Concerning Determination Separations," Jurnal Studi Agama Dan Masyarakat 10, no. 2 (2016): 233.

18 Lihat Muhammad Husain al-Dzahabi, al-Tafsir wa al-Mufassirun...39

${ }_{19}$ Lihat Muhammad Husain al-Dzahabi, al-Tafsir wa al-Mufassirun...34 penafsirannya kepada orang-orang Yahudi dan Nasroni.Hal ini dilakukan kalau memang mereka sudah tidak menemukan apapun dalam Alquran dan hadits sebagai landasan penafsiran Al-Qur'an.Kaitannya dengan orang Yahudi dan Nasroni, sahabat hanya menanyakan ayat-ayat yang masih ada kaitannya dengan kitab Taurat dan Injil, seperti ayat-ayat tentang cerita-cerita nabi dan ummat-ummat terdahulu yang memang didalam Alqurantidak dijelaskan secara rinci. Kendatipun demikian, sahabat tidak terlalu banyak merujuk kepada pendapat Ahli Kitab dan tetap memilah dan memilih apa yang mereka dengar dari Ahli kitab, apakah sesuai dengan Akidah atau Syari'at Islam atau tidak. Sumber rujukan dari Ahli Kitab ini dilakukan hanya untuk mengambil aspek nasehat (al'izah) dan pelajaran (al-'ibrah) yang terdapat dalam ayat tersebut. ${ }^{20}$

Diantara para tokoh mufasir pada masa sahabat ini adalah Abu Bakar al-Siddiq (w. 13 H.), Umar ibn Khoththob (w. 23 H), Utsman ibn 'Affan (w. 36 H), Ali ibn Abu Tholib (w. $40 \mathrm{H}$ ), Abdullah ibn Mas'ud (w. $32 \mathrm{H}$ ), Abdullah ibn 'Abbas (w. $68 \mathrm{H}$ ), Ubay ibn Ka'ab (w. 33 H), Zaid ibn Thabit (w. 48 H), Abu Musa al-Ash'ari (w. $52 \mathrm{H}$ ), Abdullah ibn Zubair). ${ }^{21}$

Setelah generasi sahabat berakhir, tabi'in yang sempat belajar tafsir kepada sahabat mulai bermunculan dengan berbagai periwayatan tafsir yang mereka warisi dari para pendahulunya.Sa'id ibn Jubair (w. $95 \mathrm{H}$ ), Mujahid (w. $104 \mathrm{H}$ ). Ikrimah (w. $104 \mathrm{H})$ dan Thawus bin Kaisan (w. $106 \mathrm{H}$ ) dan Atha' bin Abi Rabbah, merupakan sekelompok mufasir yang mewarisi keilmuan tafsir ibn Abbas (w. $68 \mathrm{H}$ ). Abu Aliyah al-Rayyahi (w. $90 \mathrm{H})$, Zaid ibn Aslam (w. 136H), dan Muhammad ibn Ka'ab al-Qardzi (w. $118 \mathrm{H}$ ) mewarisi tafsirtafsir yang diriwayatkan oleh Ubay ibn Ka'ab (w. $33 \mathrm{H}$ ).Sedangkan mufasir yang mewarisi

20 Lihat Muhammad Husain al-Dzahabi, alIsrailiyat fi al-Tafsir wa al-Hadith (Kairo: Dar alHadits, 2005), 17

${ }^{21}$ Jalaluddin Al-Suyuthi, Vol. I, al-Itqon (Beirut: dar al-Fikr, 1979,), 187 
tafsir Ibn Mas'ud (w. $32 \mathrm{H}$ ) adalah Masruq (w. $63 \mathrm{H}$ ), al-Nakha'i (w. $61 \mathrm{H}$ ), Murrah alHamdani (w. $76 \mathrm{H}$ ), Qatadah al-Sadusi (w. $117 \mathrm{H}$ ), Amir al-Syi'bi (w. $109 \mathrm{H}$ ) dan alHasan al-Basri (w. $110 \mathrm{H})^{22}$ dari merekamereka inilah, tafsir menyebar ke berbagai daerah sehingga umat Islam saat itu mudah untuk menjangkaunya.

Pergerakan tafsir pada masa tabi'in ini, sebenarnya tidak jauh berbeda dengan para pendahulunya, mereka (tabi'in) berhati-hati terhadap periwayatkan tafsir yang diperoleh dari pendahulunya, dan sumber pijakan dalam menafsirkan ayat-ayat Alquranpun tidak jauh berbeda dengan para pendahulunya. Menurut al-Qaradawi, dalam Sirah Nabi Saw kita akan menemukan hukum yang tidak sama penerapannya dalam berbagai situasi, yang terjadi karena perbedaan realitas yang melatarbelakanginya. ${ }^{23}$ Barangkali, perbedaan yang ada hanyalah pada frekuensi penafsiran tabi'in lebih banyak dibandingkan dengan penafsiran para sahabat.Selain itu, rujukan kepada Ahli Kitab juga semakin mudah dan sering dilakukan. Hal ini merupakan konsekuensi logis dari semakin luasnya wilayah Islam, yang pada akhirnya membutuhkan penafsiran beberapa ayat yang belum sempat ditafsirkan oleh para sahabat ${ }^{24}$. Di samping juga sebagai imbas dari semakin banyaknya orang-orang non Arab khususnya dari kelompok Ahli Kitab yang masuk Islam yang ingin mengetahui tantang ayat-ayat Alquranyang mengisahkan cerita-cerita Isroiliyat.

Pergerakan tafsir mengalami perkembangan dan kemajuan seiring dengan dimulainya pembukuan terhadap Hadits Nabi Saw. ${ }^{25}$ belum ada kata sepakat diantara ulama

${ }^{22}$ Lihat Muhammad Husain al-Dzahabi, al-Tafsir wa al-Mufassirun...89

${ }^{23}$ Badri Khaeruman, "Al Qardawi Dan Orientasi Pemikiran Hukum Islam Untuk Menjawab Tuntutan Perubahan Sosial," Wawasan: Jurnal Ilmiah Agama Dan Sosial Budaya 1, no. 2 (2016): 233.

\footnotetext{
${ }^{25}$ Kahalifah Umar ibn Abdul Aziz (66-101 H) yang berkuasa pada akhir Dinasti Umayyah dan awal Dinasti Abbasiyyah menerapkan kebijakan terhadap
}

dalam menentukan siapa tokoh yang pertama kali mengumpulkan Hadits seputar tafsir yang kemudian menjadi sebuah kitab tafsir. Sebagian mengatakan bahwa Ibn Juraij (80$150 \mathrm{H})$ adalah orang pertama yang mengumpulkan Hadits-Hadits Nabi Saw seputar tafsir, pendapat ini dinukil oleh Ibn Khalikan dan Ibn Taimiyyah. ${ }^{26}$ Versi lain mengatakan bahwa sebelum Ibn Juraij banyak tokoh-tokoh yang pernah menulis tafsir, salah satunya adalah Ibn Abbas, beliau pernah mendiktekan (imla') kepada muridnya, Mujahid, seperti yang dinukil Ibn Katsir. ${ }^{27}$

Ibn Jarir al-Thabari (w. $310 \mathrm{H}$ ) melalui karyanya Jami' al-Bayan fi Ta'wil Ayat Alquran diakui oleh para ulama sebagai tokoh pertama yang melakukan pembukuan tafsir secara sepesifik yang hanya memuat riwayatriwayat tafsir yang sesuai dengan urutan ayatayat Al-Qur'an. Kemudian disusul oleh Abu Bakar Ibn al-Mundzir al-Naisaburi (w. 318 H), Ibn Abi Hatim (w. 327 H), Abu al-Syaikh Ibn Hibban (w. 369 H), al-Hakim (w. 405 H), Abu Bakar Murdawaih (w. 410 H) dan lainya. ${ }^{28}$ Tafsir pada masa ini masih menggunakan metode riwayat dari Hadits Nabi, sahabat maupun tabi'in dan ulamaulama setelahnya (tabi' al-tabi'in) lengkap dengan sanadnya.Mereka sering menyelipkan pendapat-pendapat para ulama baik tentang tatabahasa, fikih ataupun ilmu kalam, yang kemudian men-tarjih-nya. Selain menggunakan riwayat dari Nabi Saw., sahabat dan tabi'in, mereka juga mengutip beberapa tafsir sebelumnya lengkap dengan sanad yang sampai kepada pengarang kitab tafsirnya. Temuan peralatan komunikasi juga

pembukuan Hadits-Hadits Nabi Saw. lihat Su'ud ibn Abdillah al-Fanisan, Ikhtilaf al-Mufassirun: Asbabuhu wa Atsaruhu (Riyadl: Dar Isybiliya, 1997), 39

${ }^{26}$ Syam al-Din Ibn Khalikan, Wafiat al-A'yan wa Anba Ibna al-Zaman Vol. III (Beirut: dar al-Shadir, 1972,),164. Ibn Taimiyyah, Majmu' al-Fatawa Vol. XX (Tk: Dar al-Wafa, 2005,), 322

${ }^{27}$ Ibn katsir, Tafsir Alquranal-Adzim Vol. I (Kairo: Maktabah Aulad al-Syaikh li al-Turats, 2000), 11

${ }^{28}$ Muhammad Husain al-Dzahabi, al-Tafsir wa alMufassirun... 104 
bekontribusi bagi perubahan-perubahan seperti ini. $^{29}$

Perkembangan tafsir pada periode ini mengalami kemajuan yang sangat sinifikan berkat kebijakan Dinasti 'Abbasiyah. Pada masa Dinasti 'Abbasiyah perkembangan keilmuan Islam sangat pesat, sehingga usahausaha penulisan dalam berbagai bidang keilmuan seperti gramatika Arab (NahwSarf), Hadits, sejarah, ilmu kalam dan lain sebagainya mendapat perhatian yang ukup besar. Mulai pada periode ini dan setelahnya, tafsir yang semula hanya bersandar pada riwayat Hadits Nabi, sahabat, tabi'in (naqlriwayat) mulai bergerak menjalar ke wilayah nalar-ijtihadi ('aqli). Hal ini sangat nampak dengan maraknya fanatisme bermadzhab dalam fikih, aliran-aliran ilmu kalam sampai bidang gramatika bahasa Arab (nahw-sarf). Mereka menafsirkan sesuai dengan golongan atau bidang keahliannya. ${ }^{30}$

Usaha menafsirkan Alquran sesuai dengan bidang yang digelutinya, terus berkembang dan berlanjut sehingga menghasilkan beratusratus kitab tafsir dengan berbagai macam ragam.Di bidang fikih terdapat tafsir Ahkam Alqurankarya Abu bakar al-Jassas (w. $370 \mathrm{H}$ ), al-Qawl al-Wajiz fi Ahkam al-Kitab al-'Aziz karya Shihab al-Din Abu al-'Abbas al-Halabi al-Samin (w. 756 H), al-Jami li Ahkam Alqurankarya Abi 'Abdillah al-Qurtubi (w. $671 \mathrm{H})$ dan lain sebagainya. Di bidang gramatika bahasa Arab (nahw-sarf) muncul tafsir Ma'ani Alquranyang dikarang oleh alZujjaj (w. $310 \mathrm{H}$ ), al-Wahidi yang mengarang kitab al-Basit, Abu al-Hayyan (w. 745 H) dengan karyanya al-Bahr al-Muhit dan lain sebagainya. Dalam bidang ilmu kalam al-Qadi 'Abd al-Jabbar (w. 415 H) dengan judul Tanzih Alquranal-Muta'in, al-Zamakhshari (w.538 H) dengan karyanya al-Kashshaf 'an Haqa'iq al-Tanzil wa 'Uyun al-Aqawil fi Wujuh al-Ta'wil dan lain sebagainya. Sedangkan di bidang filsafat terdapat Fakhr

\footnotetext{
${ }^{29}$ Lihat Jalal al-Din al-Suyuthi, al-Itqan...190-191

${ }^{30}$ Jalal al-Din al-Suyuti, al-Itqan ...190-191
}

al-Din al-Razi (w. $606 \mathrm{H}$ ) dengan maqnum opus-nya yang bertajuk Mafatih al-Gha'ib. ${ }^{31}$

Perkembangan selanjutnya, muncul tafsir Ruh al-Ma'anikarangan al-Alusi (w. $1270 \mathrm{H}$ ), disusul oleh Țantawi Jauhari (w. $1358 \mathrm{H}$ ) dengan tafsirnya al-Jawahir yang banyak memuat ilmu astronomi, kemudian diteruskan oleh Rashid Rida (w. 1354 H) lewat Tafsir alManar, Sayyid Qutb (w. 1966 M) dengan judul tafsir Fi Zilal al-Qur'an, Jamal al-Din al-Qasimi (w. $1332 \mathrm{H}$ ) yang mengarang kitab Mahasin al-ta'wil, Mustafa al-Maraghi (w. 1945 M) dengan karyanya Tafsir al-Maraghi.

Pergerakan tafsir berikutnya mulai berubah arah dan metode. Tafsir kemuadian berlanjut kea rah kajian-kajian tematik (mawdu'i) dari segala sisi Alqurandan ilmu-ilmunya. Dinatara tokoh yang menggunakan metode tematik adalah Mahmud Shaltut (w. 1963 M), Amin al-Khuli (w. 1978 M), 'Aishah Abd alRahman bint al-Shati (w. 2000 M) melalui kitab tafsirnya al-Tafsir al-bayani li al-Qur'a al-Karim.

\section{Fungsi dan Kedudukan Kaidah Kebahasaan Dalam Tafsir}

Kaidah dalam kamus Bahasa Indonesia diartikan dengan "patokan, dasar, aturan yang sudah pasti, rumusan yang menjadi hukum, asas-asas yang menjadi hukum". Sedang dalam bahasa Arab (قائدة) diartikan "asas/pondasi" jika ia dikaitkan dengan bangunan, dan ia berarti "tiang" jika dikaitkan dengan kemah. ${ }^{32}$ Sementara dalam pengertian istilah, ditemukan beberapa pengertian. Diantaranya adalah "ketetapan yang dapat diterapkan pada kebanyakan bagian-bagiannya".

Dengan demikian kaidah kebahasaan dalam tafsir, merujuk pengertian di atas dapat dirumuskan sebagai ketetapan-ketetapan yang membantu seorang penafsir untuk menyimpulkan makna dan pesan-pesan

\footnotetext{
${ }^{31}$ Muhammad Husain al-Dzahabi, al-Tafsir wa alMufassirun... 321-323, Jalal al-Din al-Suyuti, alItqan...191

${ }^{32}$ M. Qurasih Shihab, Kaidah Tafsir (Tangerang: Lentera Hati, 2013) 6-7

${ }^{33}$ M. Qurasih Shihab, Kaidah Tafsir...8
} 
Alquran serta menjelaskan ayat-ayat yang dianggap sulit (musykilah) berdasarkan Nahwu, Sharaf dan Balaghah, yang merupakan cabang-cabang ilmu yang secara khusus berkaitan dengan bahasa Arab. Dan telah disepakati oleh semua pihak, dalam beberapa ayat Alquran, Allah secara tegas menyatakan bahwa sistem isyarat yang dipilih dalam pewahyuan Alquran adalah bahasa Arab. $^{34}$

Menurut Quraish Shihab, hal ini menunjukan bahwa syarat mutlak untuk menarik makna dari pesan-pesan Alquran adalah pengetahuan tentang bahasa Arab. ${ }^{35}$ Bagi masyarakat Arab, bukti bahwa bahasa Arab dipilih sebagai bahasa Alquran dan bahasa pewahyuan semakin memperkuat asumsi-asumsi yang selama ini mereka yakini bahwa bahasa Arab merupakan bahasa yang paling kaya, paling indah dan paling sempurna jika dibandingkan dengan bahasa-bahasa nonArab (ajam). Bahkan menurut Shufyan alSauri yang dikutip oleh Ibn Katsir bahwa bahasa Arab bukan saja dipilih sebagai bahasa Alquran, tetapi juga dipilih sebagai bahasa wahyu yang merupakan bahasa kitab-kitab suci yang lainnya. Allah mewahyukan kitabkitab suci kepada para rasul dengan menggunakan bahasa Arab, dan rasul-rasul tersebut kemudian menerjemahkan atau menyampaikan kepada umatnya dalam bahasa mereka masing-masing. ${ }^{36}$ Sedangkan menurut Izutsu, bahasa Arab dipilih sebagai bahasa wahyu (Alquran) bukanlah karena nilai instrinsik bahasa Arab itu sendiri, sebagaimana asumsi-asumsi orang Arab pada umumnya, akan tetapi semata-mata hanya karena kegunaan pragmatisnya sebagai bahasa komunikasi yang efektif bagi seorang rasul yang berbangsa Arab dan masyarakat Arab

\footnotetext{
${ }^{34}$ Beberapa istilah yang digunakan untuk menunjukan bahwa bahasa Alquranadalah bahasa Arab "arabiyyan" Lihat QS. Yusuf [12]: 2, QS. Al-Ra'd [13]: 37, QS. Zukhruf [43]: 3, QS. Al-Ahqaf [46]: 12. "bi lisanin 'arabiyyin mubin" lihat QS. Al-Syu'ara [26]: 195, "arabiyyan ghaira dzi 'iwaj" lihat QS. Al-Zumar [39]: 28

${ }^{35}$ M. Qurasih Shihab, Kaidah Tafsir...35

${ }^{36}$ Lihat Ibn al-Katsir, Tafsir Ibn Katsir.....77
}

yang pertama kali disapa oleh wahyu tersebut. Hal ini bisa dilihat dari QS. Yusuf [12]: 2 dan QS. Al-Zukhruf [43]: 3 yang secara jelas menyatakan bahwa pewahyuan Alqurandalam bahasa Arab hanyalah agar kita memahaminya (la'allakum ta'qilun). ${ }^{37}$

Terlepas dari perbedaan pandangan tentang motif digunakannya bahasa Arab sebagai bahasa wahyu (Alquran), bagi umat Muslim bahasa Arab memiliki arti penting. Disamping ia sebagai bahasa yang dipilih oleh Allah, ia juga sebagai bahasa peribadatan. ${ }^{38} \mathrm{Hal}$ ini dikarenakan, Alquran merupakan kumpulan firman Allah, maka huruf-huruf, kata-kata, dan struktur bahasa yang terdapat dalam Alquran itu juga dinilai sebagai bagian dari ajaran Agama.

Meskipun bahasa Arab yang digunakan dapat dipahami karena sifat Alquran yang jelas dan dinyatakan sebagai kitab $\operatorname{mubin}^{40}$, bukan berarti ia tanpa kaidah-kaidah dalam memahaminya. Hal ini disebabkan terdapat beberapa bagian Alquran yang sulit untuk dipahami. Di dalamnya terdapat ayat-ayat mutasyabihat dan ayat-ayat yang masih samar pengertiannya yang disebabkan faktor kemujmal-an Alquranitu sendiri. Seperti lafadz musytarak, gharabah al-lafdzi, al-hadf, ikhtilaf marji' al-dhamir, al-taqdim wa alta'khir dan lain sebagainya.

Studi Alquran dapat mendukung upaya integrasi keilmuan dengan cara akomodasi penemuan ilmiah yang sistematis dengan tetap mengacu pada basis kewahyuan Alquran. ${ }^{41}$ Untuk memahami Alquran seseorang harus memperhatikan

${ }^{37}$ Lihat Izutsu, God and Man....211-213

${ }^{38}$ Hal ini terlihat pada saat sholat, tidak sah sholat seseorang yang tidak menggunakan ucapan-ucapan tertentu yang menggunakan bahasa Arab. Seperti ketika takbirat al-ihram, harus menggunakan lafadz الهه اكبر yang itu tidak boleh diganti dengan bahasa lain meskipun makna dan artinya sama.

39 H.M. Muchoyyar, "kata pengantar" dalam Nor Ichwan, Memahami Bahasa Alquran (Yogyakarta: Pustaka pelajar, 2002), X

${ }^{40}$ Lihat QS. [29]: 48, [5]: 15

41 Iskandar, "Studi Alquran Dan Integrasi Keilmuan: Studi Kasus Uin Sunan Gunung Djati Bandung. "1, Wawasan: Jurnal Ilmiah Agama dan Sosial Budaya, 1, no. 1 (2016). 89. 
beberapa aspek yang dibutuhkan sebagai perangkat keilmuan yang harus dimiliki. Hal ini dilakukan untuk meminimalisir penyimpangan dan kekeliruan dalam menafsirkan Alquran. Menurut Quraish Shihab, diantara faktor-faktor yang mengakibatkan kekeliruan dalam menafsirkan Alquran minimalnya ada enam. Pertama, subyektifitas mufasir; kedua, terdepat kekeliruan menerapkan metode atau kaidah; ketiga, sedikitnya pengetahuan ilmu-ilmu alat; keempat, sedikitnya pengetahuan terhadap uraian ayat (pembicara); kelima, mengindahkan konteks, baik dari segi asbab al-nuzul, munasabah ayat, maupun kondisi sosial masyarakat; dan keenam, tidak memperhatikan siapa pembicara dan terhadap siapa pembicaraan ditujukan. ${ }^{42}$ Sejalan dengan pernyataan diatas, al-Dzahabi mengatakan bahwa, orang yang berbicara dan menulis tafsir Alquran tanpa memiliki pengetahuan yang memadai tentang kaidah dari aturan bahasa Arab cenderung melakukan penyimpangan dalam menafsirkan Alquran dan memberikan arti etimologis suatu lafad Alquran dengan arti lain yang tidak sesuai, baik dalam arti hakiki maupun dalam arti kiasan. $^{43}$

Dari uraian tersebut, dapat diketahui bahwa pentingnya kaidah kebahasaan dalam memahami atau menafsirkan Alquran bukanlah sesuatu yang bersifat formalitas saja, akan tetapi ia merupakan sesuatu keharusan dalam upaya mengetahui makna dan kedudukan sebuah ayat Alquran sehingga darinya kita dapat lebih memahami serta dapat menjabarkanya ke dalam amaliyyah kehidupan sehari-hari $^{44}$.

\footnotetext{
${ }^{42}$ Quraish Shihab, Membumikan Alquran (Bandung: Mizan, 1997), 79

${ }^{43}$ Lihat Muhammad Husain al-Dzahabi, al-Tafsir wa al-Mufassirūn (Mesir: Dār al-Kutūb al-Haditsah, 1972), 47

${ }^{44}$ Mujahid Mustafa Bahjat and Mosidi Sally Bin Saleh, "Sheikh Bin Wan Ismail Wan Abdul Qadir (D. 1965) And His Efforts in the Field of Islamic Faith," International Journal of Nusantara Islam 1, no. 1 (2013): 106.
}

Meskipun demikian, kaidah kebahasaan yang dalam hal ini berfungsi sebagai penunt un dalam mamahami Alquran, ia tidak lepas dari istilah kritik, ini terjadi karena faktor keterbatasan bahasa itu sendiri dalam mengungkapkan sifat dan makna sebagaimana adanya sebenarnya. ${ }^{45}$ Dari sini dapat disimpulkan bahwa kaidah bahasa merupakan salah satu perangkat yang harus dimiliki oleh seseorang yang ingin memahami Alqur'an. Mengingat keterbatasan kaidah ini, maka ia pun memerlukan perangkat pendukung lainnya, seperti seseorang yang hendak memahami Alquran tidak boleh memaksakan kehendak atau pandangan pribadi. ${ }^{46}$

\section{Kaidah-Kaidah kebahasaan yang diguna- kan dalam Penafsiran}

\section{a. Damir}

Dalam menjaga penghematan terhadap penggunaan kalimat termasuk juga di dalam pengefektifan kalimat maka dhamir $^{47}$ merupakan salah satu alternatif yang efektif, dengan demikian penggunakan dhamir bertujuan untuk meringkas (ikhtisar). Seperti QS. Al-Ahzab [33]: 35

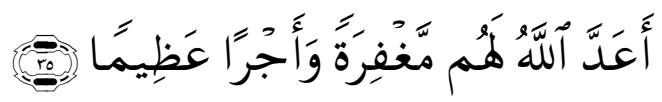

Artinya: Allah menyediakan kepada mereka ampunan dan pahala yang besar.

Menurut kaidah pokok, kesesuaian semua damir (kata ganti) dengan kata yang diruju' (marja') bertujuan untuk menghindari terjadinya kekacauan (tashtit). Seperti firman Allah QS. Țaha [20]: 39

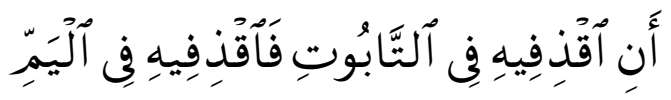

${ }^{45}$ Sukamto Said, Musykilat Mahdudiyat al-Lughah Wa Atsariha Fi 'Amaliyat Fahm Al-Nash, Tsaqafiat, Jurnal Bahasa, Peradaban dan Informasi Islam, (Vol. 1 Juli - Desember, 2000), 67

46 Al-Qardlawi, Berinteraksi dengan AlquranAlih bahasa Abdul hayyi (Jakarta: Gema Insani Press, 1999), 372

${ }^{47}$ Lihat Manna' Al-Khalil al-Qattan, Mabahis $F i$ Ulūm Alquran (Al-Qahirah: Wahbah, t.t.), 187.Damir yang terapat pada kata oه kembali pada kalimat sebelumnya. Dan jika itu dinampakan maka yang terjadi adalah pengulangan kalimat-kalimat tersebut. 
Artinya: "Letakkanlah ia (Musa) didalam peti, kemudian lemparkanlah ia ke sungai (Nil)..."

Dalam ayat tersebut, ketika kata ganti ia (أَقْذفِيدِ: yang petama kembali kepada Nabi Musa, sedangkan kata ganti ia (damir (فَأقتَذفِيهة: yang kedua kembali kepada tabut (peti), Imam Zamakhsyari dengan tegas menentangnya. Sebab hal tersebut akan menunjukan adanya ketidakselarasan (tanafur) yang bias menodai kemukjizatan Alquran. Menurutnya rujukan (marja') kedua dhamir tersebut hanya satu, yaitu Nabi Musa. Dengan demikian, pemahaman bahwa rujukan damir yang pertama kepada Nabi Musa dan yang lain kepada tabut (peti) adalah keliru atau cacat (hajnah). Sebab, pemahaman seperti itu akan mengakibatkan terjadinya ketidakselarasan susunan kalimat (tanafur alnazm) sehingga keselarasan susunanyang menjadi inti dari kemukjizatan Alquran akan hilang. Dengan demikian, memperhatikan dan menjaga Alqurandari pemahaman seperti itu merupakan kewajiban para mufasir. ${ }^{48}$

\section{b. Isim dan Fi'il}

Dalam struktur bahasa Arab, khitab yang digunakan terkadang memakai kata benda (isim) dan terkadang menggunakan kata kerja (fi'il), ${ }^{49}$ masing-masing kata tersebut mempunyai tempat tersendiri yang idak bias dipertukarkan satu dengan yang lainnya untuk tetap menghadirkan makna yang sama. Hal ini menunukan bahwa hakekat makna yang terkandung ayat akan berbeda dengan perbedaan kata yang digunakan.

Menurut al-Suyutiy, kata isim menunjukan arti tetapnya keadaan (thubut) dan kelangsungan atau kontinuitas (istimrar). Sedangkan kata fi'il menunjukan arti timbulnya sesuatu yang baru (tajaddud) dan temporal atau terjadinya suatu perbuatan(huduth). Contoh ayat yang al-

\footnotetext{
${ }^{48}$ Jalal al-Din al-Suyūti, al-Itqān fi 'Ulūm al-Qur'ān (Beirut: Resalah Publiser, 2008), 401

${ }^{49}$ Jalal al-Din Al-Suyuti, al-Itqān fi Ulūm alQur'an...420-421
}

khitabnya menggunakan kata isim QS. AlHujurat [49]: 15

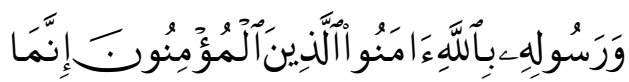

"Orang-orang yang beriman itu tentulah orang-orang yang percaya (beriman) kepada Allah dan Rasul-Nya"

Pada ayat tersebut penyebutan almu'minun yang menggunakan kata isim, ini menunjukan bahwa keimanan merupakan sesuatu yang tetap dan terus berlangsung selama keadaan masih menghendakinya, sebagaimana halnya ketaqwaan dan kesabaran. Walhasil, pemakaian kata almu'minun pada ayat diatas menggambarkan bahwa keimanan seseorang tidak terjadi secara temporer, akan tetapi keimanan tersebut terus berlangsung dan berkesinambungan. Oleh karena itu, seseorang dikatakan mu'min karena keberadaanya senantiasa diliputi oleh rasa iman.

Sedangkan contoh ayat Alquran yang alkhitab-nya menggunakan kata fi'il adalah QS. Al-Baqarah [2]: 274

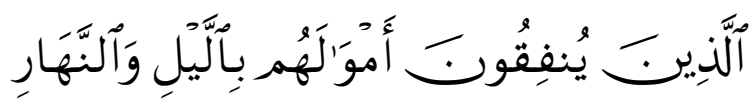

"Orang-orang yang menafkahkan hartanya di malam dan di siang hari"

Ayat diatas menjelaskan tentang nafaqah, yang dituangkan dalam bentuk kata fi'il, yaitu yunfiquna. Hal ini dimaksudkan bahwa pemberian nafaqah itu bersifat temporer, terkadang ada terkadang tidak ada.

\section{c. Nakirah dan Ma'rifat}

Masing-masing dari isim nakirah dan ma'rifat mempunyai kedudukan khusus yang tidak sesuai untuk yang lainnya, begitu juga tentang fungsi penggunaannya sesuai dengan konteksnya. Berikut adalah beberapa fungsi penggunaan isim nakirah dalam ayat-ayat AlQur'an: ${ }^{50}$

a. Menunjukan arti satu/tunggal (iradah alwahdah) seperti QS. Yasin [36]: 20

\footnotetext{
${ }^{50}$ Jalal al-Din Al-Suyuti, al-Itqān fi Ulūm alQur'an...405
} 
b. Menunjukan ragam atau macam (iradah al-naw ${ }^{\circ}$ ) seperti QS. Al-Baqarah [2]: 96

c. Mengagungkan/menghormati (al-ta'zim) seperti QS. Al-Baqarah [2]: 279

d. Menunjukan jumlah yang banyak (altakthir) sepertiQS. Al-Syu'ara [26]: 41

e. Menghinakan/meremahkan (al-tahqir) seperti QS. 'Abasa [80]: 19

f. Menunjukan jumlah yang sedikit (altaqlil) seperti QS. Al-Taubah [9]: 72

Adapun fungsi penggunaan isim ma'rifat sesuai dengan bentuknya dalam ayat-ayat Alquranadalah sebagai berikut: ${ }^{51}$

a. Ta'rif dengan domir

Untuk meringkas (baik sebagai mutakallim, mukhatab, ataupun gha'ib). Seperti dalam QS. Al-Ahzab [33]: 35

b. Ta'rif dengan isim 'alam

1) Menghadirkan pemilik nama itu dalam hati pendengar dengan cara menyebutkan namanya yang khas. Seperti QS. Al-Ikhlas [112]: 1

2) Memuliakan. Seperti dalam QS. AlFath [48]: 29

3) Merendahkan /meremehkan. Contoh QS. Al-Lahab [111]: 1

c. Ta'rif dengan Isim Isharah

1) Membedakan atau mengistimewakan (al-tamyiz), seperti QS. Luqman [31]: 11

2) Sindiran (al-Ta'rid), untuk memberi sindiran atas ketidaktahuan pendengar sehingga ia akan dapat membedakan sesuatu setelah ada isyarat yang meyakinkan. Seperti QS. Luqman [31]: 11

3) Merendahkan dari dekat (al-Tahqir), seperti QS. Al-Ankabut [29]: 64

4) Mengagungkan dari jauh (a-Ta'zim), seperti QS. Al-Baqarah [2]: 2

d. Ta'rif dengan Isim Mawsul

1) Ketidaksenangan atas penyebutan nama aslinya, baik dengan alasan melindungi, merendahkan ataupun yang lainnya. Seperti QS. Al-Ahqaf [46]: 17

\footnotetext{
${ }^{51}$ Jalal al-Din Al-Suyuti, al-Itqān fi Ulūm alQur'an...406-407
}

2) Menunjukan arti umum, seperti QS. Al-Ankabut [29]: 69

3) Meringkas kalimat, seperti QS. AlAhzab [33]: 69

e. Ta'rif dengan Alif Lam

1) Menunjukan sesuatu yang sudah diketahui karena telah disebutkan sebelumnya. Seperti QS. Al-Nur [24]: 35

2) Menunjukan sesuatu yang telah diketahui oleh pendengarnya. Seperti QS. Al-Fath [48]: 18

3) Menunjukan hakikat makna secara keseluruhan. Seperti QS. Al-'Ashr [103]: 2

4) Menunjukan seluruh pengertian yang tercakup di dalamnya. Contoh QS. AlNisa' [4]: 2

f. Ta'rif dengan Idafah pada salah satu isim ma'rifat diatas.

1) Memuliakan Mudaf, seperti QS. AlHijr [15]: 42

2) Menunjukan arti umum, seperti QS. Al-Fatir [35]: 3

Apabila terjadi pengulangan dalam penyebutan kata isim, maka dalam hal ini terdapat empat kemungkinan, ${ }^{52}$ yaitu:

a. Keduanya isim ma'rifat. Maka kaidah yang berlaku adalah bahwa yang kedua adalah pada hakikatnya yang pertama. Contoh QS. Al-Fatihah [1]: 6-7

b. Keduanya isim nakirah. Maka kaidah yang berlaku adalah bahwa yang kedua bukanlah yang pertama. Seperti QS. AlRum [30]: 54

c. Pertama isim nakirah dan yang kedua isim ma'rifat. Maka isim yang disebutkan kedua pada hakikatnya adalah yang pertama. Seperti QS. Al-Muzammil [73]: 15-16

d. Pertama isim ma'rifat dan yang kedua isim nakirah. Maka apa yang dimaksudkan tergantung pada konteks atau indicator (qarinah). Kadang konteks tersebut menunjukan arti yang berbeda, seperti QS. Al-Rum [30]: 55. Terkadang

\footnotetext{
${ }^{52}$ Jalal al-Din Al-Suyuti, al-Itqān fi Ulūm alQur'an...407-410
} 
juga konteks tersebut menunjukan arti yang sama, seperti QS. Al-Zumar [39]: $27-28$

\section{d. Al-Su'al wa Al-Jawab}

Menurut kaidah dasar bahwa setiap al$j a w a b^{53}$ harus sesuai dngan al-su'al (pertanyaan), jika pertanyaan itu meminta jawaban yang jelas. Meskipun demikian, dalam Alquranterdapat beberapa jawaban yang tidak sesuai dengan pertanyaan, hal ini dimaksudkan untuk menginformasikan bahwa jawaban itulah yang seharusnya ditanyakan. Jawaban yang demikian oleh Al-Sakaki disebut sebagai al-ushūb al-hakim.

a. Khalid 'Abd. Al-Rahman telah mengidentifikasi beberapa pola kaidah alsu'al dan al-jawab yang terdapat dalam Al-Qur'an: Jawabannya bersambung dengan pertanyaannya (muttashil). Contoh QS. Al-Baqarah [2]: 215

b. Jawabannya terpisah dengan pertanyaanya (munfashil). Contoh QS. Al-Furqan [25]: 7, dijawab pada surat yang sama tapi beda ayat, yaitu QS. AlFurqan [25]: 20

c. Dua jawaban dalam dua surat yang berbeda untuk satu pertanyaan. Contoh QS. Zukhruf [43]: 31-32. Peranyaan pada QS. Zukhruf [43] tersebut dijawab dengan dua jawaban yang berbeda pada dua surat yang berbeda. Jawaban pertama pada QS. Al-Zukhruf [43]: 32dan jawaban kedua pada QS. Al-Qashshash [28]: 68

d. Satu pertanyaan yang jawabannya tidak disebutkan. Contoh QS. Muhammad [47]: 14

e. Jawaban yang mendahului pertanyaan. Contoh QS. Șad [38]: 1, yang merupakan jawaban terhadap pertanyaan dari QS. Șad [38]: 4

\section{SIMPULAN}

Untuk memahami Alquran yang berbahasa Arab, baik dari segi arti dan makna, maka diperlukan sebuah penafsiran. Dalam upaya menafsirkan Alquran dibutuhkan kaidah tafsir, guna menghasilkan sebuah penafsiran yang baik dan komplek. Kaidah tafsir, mempunyai hubungan yang sangat erat dengan bahasa Arab, dimana kaidah tafsir harus didukung oleh kaidah-kaidah dasar dan kaidah kebahasaan (al-qawa'id allughawiyyah).

Dengan demikian, kedudukan kaidah kebahasaan menempati posisi yang sangat penting dalam penafsiran Alquran. Ia merupakan alat bantu bagi para mufasir sehingga menghasilkan penafsiran yang baik dan komplek. Disamping juga mampu meminimalisir terjadinya penafsiran yang serampangan, karena tidak sesuai dengan kaidah-kaidah yang telah dirumuskan oleh para pendahulu.

\section{DAFTAR PUSTAKA}

Abu Hayyan. Tafsir al-Bahr al-Muhit. Beirut: Dar al-Kutub al-Ilmiyyah, 1993, vol. I alSuyuti, Jalal al-Din. al-Itqan. Beirut: Dar al-Fikr, tt. Vol. II

al-Alusi, Syihab al-Din. Ruh al-Ma'ani.

Beirut: Ihya' al-Turath al-Arabi, tt, vol. I

al-Dzahabi, Muhammad Husain. al-Israiliyat

fi al-Tafsir wa al-Hadith. Kairo: Dar alHadits, 2005

al-Fanisan, Su'ud ibn Abdillah. Ikhtilaf al-

Mufassirun: Asbabuhu wa Atsaruhu.

Riyadl: Dar Isybiliya, 1997

al-Qardlawi. Berinteraksi dengan AlquranAlih bahasa Abdul hayyi. Jakarta: Gema Insani Press, 1999

al-Qattan, Manna' Al-Khalil. Mabahith $F i$ 'Ulum Al-Qur'an.Al-Qahirah: Wahbah, tt.

al-Sabt, Khalid ibn 'Uthman. Qawa'id al-

Tafsir": Jam'an wa Dirasatan. tt. Dar ibn 'Affwan, $1421 \mathrm{H}$

al-Suyuti, Jalal al-Din. al-Itqan fi 'Ulum alQur'an. Beirut: Resalah Publiser, 2008

al-Zarkashi, Badr al-Din. al-Burhan fi 'Ulum al-Qur'an. Beirut: Dar al-Kutub al-Ilmiyah, 2006

\footnotetext{
${ }^{53}$ Jalal al-Din Al-Suyuti, al-Itqānfi Ulūm alQur'an...416-419
} 
al-Zarqani, Muhammad Abd. Al-Dim.Manahil al-Irfan Fi 'ulum al-Qur'an.Beirut: Dar alFikr, tt.

Amin, Ahmad. Fajr al-Islam.Beirut: Dar alKutub al-Ilmiyah, 2004

Anwar, Rosihon, Dadang Darmawan, and Cucu Setiawan. "Kajian Kitab Tafsir Dalam Jaringan Pesantren Di Jawa Barat." Wawasan: Jurnal Ilmiah Agama Dan Sosial Budaya 1, no. 1 (2016): 56-69.

Badri Khaeruman. "Al Qardawi Dan Orientasi Pemikiran Hukum Islam Untuk Menjawab Tuntutan Perubahan Sosial." Wawasan: Jurnal Ilmiah Agama Dan Sosial Budaya 1, no. 2 (2016): 227-38.

Bahjat, Mujahid Mustafa, and Mosidi Sally Bin Saleh. "Sheikh Bin Wan Ismail Wan Abdul Qadir (D. 1965) And His Efforts in the Field of Islamic Faith." International Journal of Nusantara Islam 1, no. 1 (2013): 106-18.

Fatmawati. "Inter-Religious Relations In The Period Of Prophet Muhammad." Al-Albab 5, no. 2 (2016): 175-93.

Hikmawati, Fenti. "Islamic Counselling Model to Increase Religious Commitment (Study of Students at the University UIN Bandung)." International Journal of Nusantara Islam 1, no. 1 (2013): 65-81.

Ibn Faris, Mu'jam Maqayis al-Lughah.Beirut: Dar al-Fikr, 1979, vol. IV

Ibn katsir, Tafsir Alquranal-Adzim. Kairo: Maktabah Aulad al-Syaikh li al-Turats, 2000, Vol. I
Ibn Khalikan, Syam al-Din. Wafiat al-A'yan wa Anba Ibna al-Zaman. Beirut: dar alShadir, 1972, Vol. III

Ibn Taimiyyah, Majmu' al-Fatawa.Tk: Dar alWafa, 2005, Vol. XX

Iskandar, Syahrullah. "Studi AlQuran Dan Integrasi Keilmuan: Studi Kasus UIN Sunan Gunung Djati Bandung." Wawasan: Jurnal Ilmiah Agama Dan Sosial Budaya 1, no. 1 (2016): 13-14.

Kholis, Nur. Pengantar studi Alqurandan Hadist. Yogyakarta: Teras, 2008

Muchoyyar, H.M. "kata pengantar" dalam Nor Ichwan, Memahami Bahasa AlQur'an. Yogyakarta: Pustakapelajar, 2002

Qosim. "Analysis of Critical Thought Wahbah Wahbah Az-Zuhailī Concerning Determination Separations." Jurnal Studi Agama Dan Masyarakat 10, no. 2 (2016): 233-56.

Said, Sukamto.Musykilat Mahdudiyat alLughoh Wa Atsariha Fi 'Amaliyat Fahm Al-Nash, Tsaqafiat, Jurnal Bahasa, Peradaban dan Informasi Islam, Vol. 1 Juli - Desember, 2000

Solahudin, Muhammad. "Metodologi Dan Karakteristik Penafsiran Dalam Tafsir AlKashshaf." Wawasan: Jurnal Ilmiah Agama Dan Sosial Budaya 1, no. 1 (2016): 11626.

Shihab, M. Qurasih.Kaidah Tafsir. Tangerang: Lentera Hati, 2013 